Available online at: https://proceeding.researchsynergypress.com/index.php/rsfconferenceseries1

RSF Conference Series: Business, Management and Social Sciences

e-ISSN 2807-5803/ p-ISSN 2807-6699

Volume 1Number 4 (2021): 202-209

\title{
Model of Independent Learning - Independent Campus to Disseminate Risk Disaster Awareness: Merapi Volcano Eruption Management Planning
}

\author{
Eko Teguh Paripurno1, Nandra Eko Nugroho², Aditya Pandu Wicaksana3 ${ }^{3}$, Gandar Mahojwala ${ }^{4}$ \\ 1, 2, 3 University of Pembangunan Nasional "Veteran" Yogyakarta \\ ${ }^{4}$ KAPPALA Indonesia
}

\begin{abstract}
Students' abilities are obtained not only from inside the classroom but outside the campus practice will be able to increase knowledge and provide hands-on experience. Independent Learning Independent Campus provides an opportunity for this to be done. One form of learning activity for the Independent Learning - Independent Campus program is being involved in humanitarian projects. With students involved in humanitarian missions, learning outside the classroom is carried out and students gain experience by providing solutions to problems in disaster-prone areas according to their expertise. Merapi volcano is an area that can be used as a learning for students. Preparedness is an activity that will provide students with experience and knowledge. This study plans a curriculum for student activities in the post-village contingency plan process, and in a participatory manner to obtain community agreement through a focus group discussion process with participatory rural appraisal tools, so that the placement of student functions can be following the needs of the residents.
\end{abstract}

Keywords: contingency plan, merapi eruption, independent learning, disaster awareness.

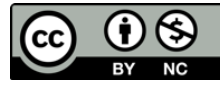

This is an open access article under the CC-BY-NC license

\section{INTRODUCTION}

The Independent Learning - Independent Campus program aims to prepare students to have the competence to be able to compete and be tough to face the times. Innovative learning will produce maximum achievements and according to developing conditions. For this reason, it is necessary to design and practice what has been carried out. One of the goals of the Independent Learning Independent Campus is that gaining knowledge is not only done indoors but also from nature or outside the campus. So that learning and knowledge can be obtained from anyone and anywhere. Among the learning places that can be used as locations are in areas prone to the eruption of the Merapi volcano.

Since 2019, the University of Pembangunan Nasional Veteran Yogyakarta has been involved in the preparation of this contingency plan as a substance team, including involvement in the preparation of contingency plans in each village. Functionally, students can be involved to broaden their horizons and deepen their expertise following the activities carried out by the community listed in the contingency plan. Thus, this research will connect the student's capacity to the community's needs in every village, by utilizing Participatory Rural Appraisal (PRA) sessions with the community.

\section{LITERATURE REVIEW}

The development of the Merapi volcano's activity is still on alert status, and the growth of the dome is also relatively stable. Visually monitored at any time there could be an increase in activities that threaten safety and property loss. The occurrence of lava avalanches makes it possible for the pyroclastic flow to occur. The lava dome appears at the center of the crater, tending to the West- 
Northwest, until the center of the 2010's dome (Regional Disaster Management Agency of Sleman District 2020).

Lava domes can be built with a maximum volume of 10 million $\mathrm{m} 3$. The growth of the large dome resulted in instability/collapse of the crater wall in the West and South sectors (around the crater opening). When the lava dome is unstable, part of it will collapse towards the current crater opening and also towards the opening due to the collapse of the crater wall. This scenario refers to most Merapi-type eruptions that collapse old lava such as the 1998 and 2006 eruptions. Indonesia Geological Disaster Technology Research and Development Center (BPPTKG) estimates pyroclastic flow slopes for Kuning River, Boyong River, Krasak River, Putih River, Senowo River, Trising River, Apu River based on the scenario of an additional crater opening. in the south and west (Regional Disaster Management Agency of Sleman District 2020).

Contingency planning is the preparation of action plans that will be activated if the predicted scenario occurs. The planning involves all sectors and elements of society in the form of agreement and continuous collaboration to formulate and define the responsibilities and actions that must be taken or carried out by each party. The Contingency Plan is a quick and effective emergency response guideline, to meet the needs of refugees and evacuations, which is prepared by a village emergency response organization consisting of the emergency response command, deputy commander, secretariat, and fields as needed, from the operational, health, logistics, refugee camps, information, education, animal husbandry, and security. Even in this Covid-19 situation, by using their local resources, the community could prevent and rehabilitate the transmission and impact of Covid-19, thus reducing the bigger risk of Covid-19 that could occur. Every community at each level, even without the huge support of funding could survive the crisis if manage and optimize their capital asset (Regional Disaster Management Agency of Sleman District 2020).

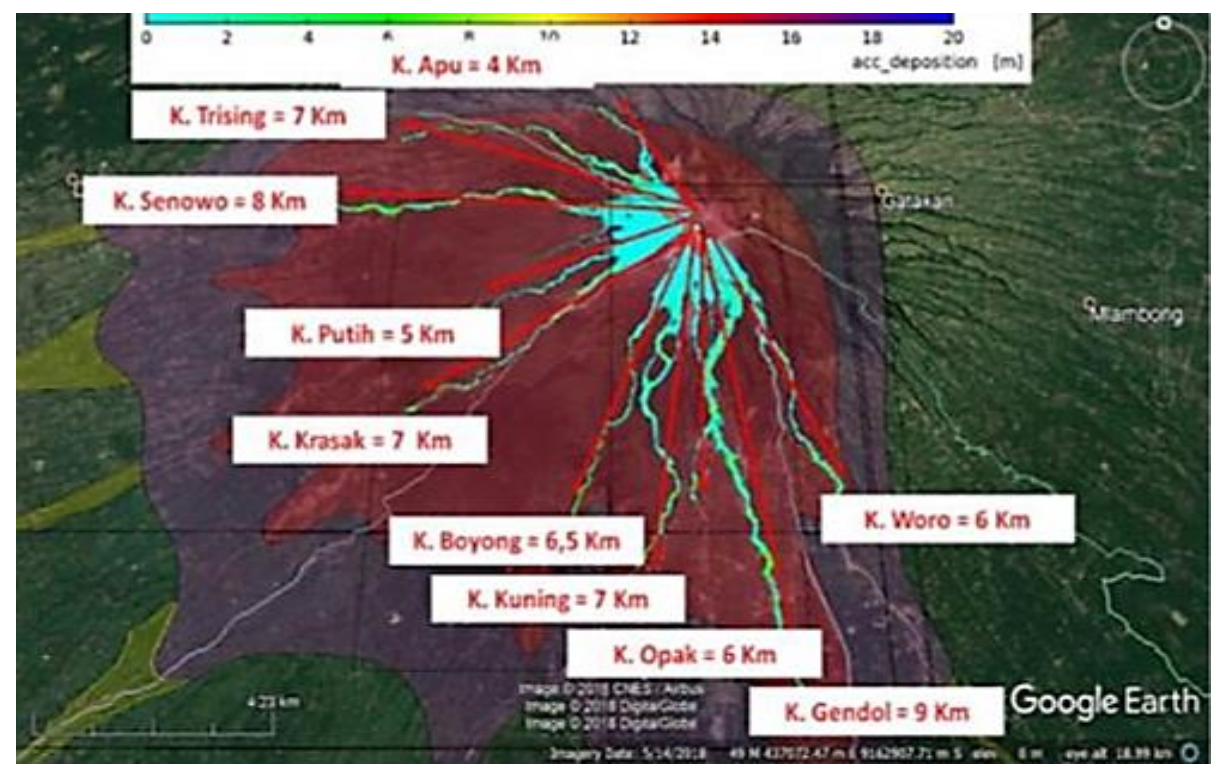

Figure 1. The coverage area affected by the pyroclastic flow hazard is south-southeast, west-southwest (Regional Disaster Management Agency of Sleman District 2020) 


\section{RESEARCH METHODOLOGY}

This research is qualitative research using Participatory Rural Appraisal (PRA) tools. PRA is a set of participatory approaches and methods to learn about rural life and conditions by, together, and from rural communities (Chambers 1994). The research was conducted in the form of documentary and exploratory studies of community and stakeholder practices. The documentary study was carried out by re-reading the document of program activities carried out by the communities in dealing with Covid-19. Explorative assessments were carried out directly with interviews representing communities in Tembi Hamlet. The use of PRA tools is certainly consistent with qualitative research which has the core of understanding society through their frame of reference. The PRA technique was formed by drawing directly from qualitative social research. Launched from Campbell, that PRA is part of qualitative research (Campbell 2001). In disaster risk reduction, PRA is a key assessment tool to help choose meaningful and useful strategies for vulnerable communities (Konze \& Holloway 1996). PRA as an approach to assess risks as well as vulnerabilities and capacities is a valuable method in disaster reduction planning at the community level. From a disaster reduction perspective, PRA is one tool that can be used to assess key vulnerabilities and capacities, as these relate to the risks faced by disasterprone communities. Compared to other assessment methods, PRA is particularly powerful, as it: a) actively involves community; b) empowers the community to identify the risks and priorities, as well as capacities to reduce these risks; c) provides a picture of the community's perceptions of the risks it faces; d) allows both community insiders and outsiders to jointly identify risk reduction measures - is both time and cost-effective (Konze \& Holloway 1996).

\section{FINDING AND DISCUSSION}

FGD sessions with PRA tools in Glagaharjo, Kepuharjo, Umbulharjo, Hargobinangun, Purwobinangun, Girikerto, and Wonokerto village, result in three findings: 1) all villages are open to receiving students from Independent Learning - Independent Campus program; 2) the community - as the mentor of the students - could explain what students will learn in their humanitarian activity in Merapi volcano, and; 3 ) the community could specify the student involvement in community activities, as explained below by Table 1.

The results of the FGD, by carrying out this independent learning activity, there are at least three things that the participants imagine that students will get, namely:

1. Understand the practical guidelines when managing emergencies.

2. Able to explain and conduct analysis of action during a disaster emergency, including the phases regarding the minimum standards that must be met, as well as the concept of not harm when handling an emergency. 
Model of Independent Learning - Independent Campus to Disseminate Risk Disaster Awareness: Merapi Volcano Eruption Management Planning Eko Teguh Paripurno, Nandra Eko Nugroho, Aditya Pandu Wicaksana, Gandar Mahojwala

\section{Table 1. Students involvement in community activities}

\begin{tabular}{|c|c|c|}
\hline Structure & Function & Role of Students \\
\hline Executive Unit & $\begin{array}{l}\text { Ensure and Coordinate in all fields related to the } \\
\text { handling of the emergency response to the eruption } \\
\text { of Merapi volcano in the COVID-19 pandemic } \\
\text { situation in the village scope. This unit has a major } \\
\text { role in carrying out comprehensive and integrated } \\
\text { emergency response activities. Executive unit } \\
\text { coordinates with key stakeholders related to } \\
\text { disaster emergency response. }\end{array}$ & $\begin{array}{l}\text { 1. Processing information from the Data, Information, } \\
\text { Communication Team of the Village Headquarters to be } \\
\text { forwarded to the community. } \\
\text { 2. Assist in documenting reports from all areas related to results } \\
\text { and progress; } \\
\text { 3. Prepare daily reports on emergency response activities; } \\
\text { 4. Processing and controlling the flow of information in and out } \\
\text { as the main source of information. }\end{array}$ \\
\hline $\begin{array}{l}\text { Data, } \\
\text { Information, and } \\
\text { Communication } \\
\text { Sector }\end{array}$ & $\begin{array}{l}\text { Ensure that all information/input regarding } \\
\text { decision making and dissemination of early } \\
\text { warning information and communication on the } \\
\text { development of the situation for the eruption of } \\
\text { Merapi volcano in the COVID-19 pandemic situation } \\
\text { is conveyed properly and correctly to all residents } \\
\text { of the villages. }\end{array}$ & $\begin{array}{l}\text { 1. Gathering information from all government sources } \\
\text { 2. Assist in communication with relevant key stakeholders to } \\
\text { support hazard monitoring and warning tasks; } \\
\text { 3. Assist in monitoring and providing recommendations to the } \\
\text { Executive Unit to support immediate action. }\end{array}$ \\
\hline $\begin{array}{l}\text { Secretary and } \\
\text { Treasurer }\end{array}$ & $\begin{array}{l}\text { Preparing logistics administration includes: 1) } \\
\text { reception; 2) expenditure; 3) accountability report; } \\
\text { 4) information board. }\end{array}$ & $\begin{array}{l}\text { Secretary } \\
\text { 1. Record and document all activities } \\
\text { 2. Carry out daily goods distribution reporting } \\
\text { 3. Help other sub-sections in need } \\
\text { 4. List and distribute external volunteer assistance } \\
\text { Treasurer: } \\
\text { 1. Recording receipts, use, and financial administration }\end{array}$ \\
\hline $\begin{array}{l}\text { Livestock } \\
\text { Evacuation and } \\
\text { Transportation }\end{array}$ & $\begin{array}{l}\text { Ensure the evacuation process for residents, } \\
\text { tourists, and the livestock according to the } \\
\text { permanent emergency evacuation procedures } \\
\text { following the COVID-19 health protocol. The } \\
\text { evacuation team is responsible for carrying out }\end{array}$ & $\begin{array}{l}\text { 1. Develop and create a plan for the evacuation route; } \\
\text { 2. Help ensure that the evacuation route is safe for villagers to } \\
\text { pass, both at the gathering point and heading to the refugee } \\
\text { barracks; } \\
\text { 3. Assist in the evacuation of residents and livestock from the }\end{array}$ \\
\hline
\end{tabular}


Model of Independent Learning - Independent Campus to Disseminate Risk Disaster Awareness: Merapi Volcano Eruption Management Planning Eko Teguh Paripurno, Nandra Eko Nugroho, Aditya Pandu Wicaksana, Gandar Mahojwala

\begin{tabular}{|c|c|c|}
\hline & $\begin{array}{l}\text { searches and helping residents who are not yet at } \\
\text { the gathering point to get to the final evacuation } \\
\text { location. The evacuation and transportation team } \\
\text { coordinates with the health team, and reports } \\
\text { activities to the Chief Executive of village response. }\end{array}$ & $\begin{array}{l}\text { assembly point to the refugee barracks; } \\
\text { 4. Assist in the search for residents who are not yet at the } \\
\text { gathering point or in the refugee barracks; } \\
\text { 5. Assisting in the preparation of emergency evacuation fleets, } \\
\text { sweeping and searching health and education sectors; } \\
\text { 6. Help ensure that operations carried out by the Evacuation and } \\
\text { Transportation Sector must comply with the COVID-19 Health } \\
\text { Protocol } \\
\text { 7. Assist in reporting progress to the Chief Executive of the village } \\
\text { response }\end{array}$ \\
\hline $\begin{array}{l}\text { Barracks, Non- } \\
\text { Barracks, and } \\
\text { Livestock Refuge }\end{array}$ & $\begin{array}{l}\text { Ensure that the preparation of refugee camps, both } \\
\text { barracks, and non-barracks, as well as livestock } \\
\text { barracks, can be used during the emergency } \\
\text { conditions of the eruption of Merapi volcano and are } \\
\text { following the Covid-19 health protocol for } \\
\text { evacuation locations for residents }\end{array}$ & $\begin{array}{l}\text { Barracks } \\
\text { 1. Assist in the preparation of refugee camps and all their } \\
\text { facilities and infrastructure following the Covid-19 protocol, } \\
\text { including places for independent isolation/quarantine both at } \\
\text { Refugee Barracks and Non-Refugee Barracks locations; } \\
\text { 2. Assist in collecting data on disaggregated refugees; } \\
\text { 3. Assist in coordinating the basic needs of refugees and be } \\
\text { responsible for the handling of refugees in the locations of } \\
\text { Refugee Barracks and Non-Refugee Barracks; } \\
\text { Assist in the preparation of the cattle barracks and all its } \\
\text { facilities and infrastructure; } \\
\text { Assist in collecting data on the identity of residents' livestock; } \\
\text { Assist in the coordination and preparation of residents' } \\
\text { livestock needs while at the livestock barracks location; } \\
\text { 7. Helping to stimulate the economic activities of the residents in } \\
\text { the refugee camps. } \\
\text { Assist in reporting progress to the Chief Executive of the village } \\
\text { daily; }\end{array}$ \\
\hline
\end{tabular}


Model of Independent Learning - Independent Campus to Disseminate Risk Disaster Awareness: Merapi Volcano Eruption Management Planning Eko Teguh Paripurno, Nandra Eko Nugroho, Aditya Pandu Wicaksana, Gandar Mahojwala

\begin{tabular}{|c|c|c|}
\hline & & $\begin{array}{l}\text { 2. Assist in identifying the number and basic needs in refugees } \\
\text { camps, both in barracks and non-barracks, including } \\
\text { independent ones; } \\
\text { 3. Assist in providing and serving the fulfillment of basic needs for } \\
\text { refugees; } \\
\text { 4. Assist in providing equipment and supplies for other teams. } \\
\text { 5. Assist in the management of kitchens for all refugee barracks; } \\
\text { 6. Assist in the management of food needs for the elderly, } \\
\text { pregnant and lactating women, infants - toddlers and children, } \\
\text { sick people with special menu needs; } \\
\text { 7. Assist in reporting progress to the Village Chief Executive } \\
\text { 8. Help ensure that all operations in the Logistics and Public } \\
\text { Kitchens must comply with the Covid-19 Health Protocol } \\
\text { Clean Water and Sanitation } \\
\text { 1. Assist in the management of clean water distribution in } \\
\text { refugee and non-barrack camps } \\
\text { Assist in the management of bathroom at the location of } \\
\text { refugee barracks and non-refugee barracks } \\
\text { Helping the distribution of needs and management of non- } \\
\text { medical waste }\end{array}$ \\
\hline $\begin{array}{l}\text { General Health } \\
\text { and Handling } \\
\text { Covid-19 }\end{array}$ & $\begin{array}{l}\text { Ensure that all affected residents can get access to } \\
\text { basic health services and provide first aid } \\
\text { assistance to victims who experience health } \\
\text { problems as well as Covid-19 screening. }\end{array}$ & $\begin{array}{l}\text { 1. Assist in the support of health services for victims in } \\
\text { refugee camps (barracks and non-barracks); } \\
\text { 2. Implement trauma and psychosocial support; } \\
\text { 3. Assist in the preparation of first aid drugs in emergencies; } \\
\text { 4. Assist in the identification and screening of refugees by } \\
\text { using a monitoring form whether they fall into the category } \\
\text { of ordinary complaints, close contacts, or confirmed Covid- } \\
\text { 19 } \\
\text { 5. Assist in the separation of refugees based on screening } \\
\text { results. } \\
\text { 6. Assist the handling of refugees who must self-isolate in the } \\
\text { provided barracks } \\
\text { 7. Assist the handling of refugees who must be referred to the }\end{array}$ \\
\hline
\end{tabular}


Model of Independent Learning - Independent Campus to Disseminate Risk Disaster Awareness: Merapi Volcano Eruption Management Planning Eko Teguh Paripurno, Nandra Eko Nugroho, Aditya Pandu Wicaksana, Gandar Mahojwala

\begin{tabular}{|c|c|c|}
\hline & & $\begin{array}{l}\text { local health service, the nearest hospital, or the Hajj } \\
\text { Dormitory } \\
\text { 8. Assist in coordination for follow-up plans and reporting } \\
\text { 9. Assist in reporting progress to the village coordinator. }\end{array}$ \\
\hline Security & $\begin{array}{l}\text { Plays a role in supporting regional security, both in } \\
\text { refugee barracks, livestock barracks and in village } \\
\text { areas. This includes monitoring and enforcing the } \\
\text { implementation of the Covid-19 health protocol in } \\
\text { all areas of emergency response operations for the } \\
\text { eruption of the Merapi volcano in the Covid-19 } \\
\text { situation. }\end{array}$ & $\begin{array}{l}\text { 1. Assist and support security activities in refugee barracks } \\
\text { and livestock barracks; } \\
\text { 2. Assist and support security activities in the village area; } \\
\text { 3. Monitor and ensure that the Covid-19 health protocol is } \\
\text { carried out properly in all fields of emergency response } \\
\text { operations for the Merapi volcano Eruption } \\
\text { 4. Provide progress reports to the village coordinator; } \\
\text { 5. Assist in screening volunteers by going through a letter of } \\
\text { assignment from the Main Post }\end{array}$ \\
\hline $\begin{array}{l}\text { Child and Public } \\
\text { Protection and } \\
\text { Complaints } \\
\text { Mechanism }\end{array}$ & $\begin{array}{l}\text { Ensure that child and public protection is carried out } \\
\text { in refugee camps. }\end{array}$ & $\begin{array}{l}\text { 1. Assist in the facilitation of complaints and refugee services } \\
\text { (related to the protection of rights, meeting the needs of } \\
\text { children, women, and vulnerable groups). } \\
\text { 2. Monitor and ensure the fulfillment of the right to clean } \\
\text { and healthy lifestyle needs and the implementation of the } \\
\text { Covid-19 health protocol } \\
\text { 3. Assist in reporting progress to the village Disaster } \\
\text { Emergency Management Coordinator }\end{array}$ \\
\hline Education & $\begin{array}{l}\text { Ensure the continuity of teaching and learning } \\
\text { activities and schools continue to run in } \\
\text { emergencies. }\end{array}$ & $\begin{array}{l}\text { 1. Assist in the activation of evacuation procedures according } \\
\text { to the evacuation procedures of the School Resilience } \\
\text { Team. } \\
\text { 2. Help the student mentoring and learning process }\end{array}$ \\
\hline
\end{tabular}


RSF Conference Series: Business, Management and Social Sciences

Volume 1Number 4 (2021): 202-209

Model of Independent Learning - Independent Campus to Disseminate Risk Disaster Awareness: Merapi Volcano Eruption Management Planning

Eko Teguh Paripurno, Nandra Eko Nugroho, Aditya Pandu Wicaksana, Gandar Mahojwala

\section{CONCLUSION}

The village contingency plan has a structure with a function that can accept students as volunteers as well as learners. Student involvement is determined from priority actions in the contingency plans for each village that have been agreed upon by the PRA sessions that have been carried out in each village, so that through the Independent Learning - Independent Campus program, students can learn from the community as their mentor in disaster management.

\section{REFERENCES}

Campbell, J.R., 2001, 'Participatory rural appraisal as qualitative research: Distinguishing methodological issues from participatory claims', Human Organization, 60(4), 380-389.

Chambers, R., 1994, 'The origins and practice of rural appraisal', World Development, 22(7), 953-969.

Konze, A. Von \& Holloway, A., 1996, Reducing risk : participatory learning activities for disaster mitigation in Southern Africa.

Regional Disaster Management Agency of Sleman District, 2020, Merapi Volcano Eruption Contingency Plan Document Adaptation to Health Protocol. 